\title{
ANALISIS YURIDIS KESADARAN HUKUM BERASURANSI PEDAGANG DI LINGKUNGAN PASAR KOTA MEDAN *
}

\author{
Mulhadi $^{\text {*** }}$ dan Zulfi Chairi ${ }^{* * *}$ \\ Departemen Hukum Perdata, Fakultas Hukum, Universitas Sumatera Utara \\ Jalan Universitas No.4 Kampus USU, Medan, Sumatera Utara, 20155
}

\begin{abstract}
Insurance legal awareness is very important. Legal awareness is like a bridge that connects traders with their rights and obligations. Traders in Medan City interested insured caused by factors as the risk of losses were taken over by the insurance company, feel safe from the hazard, the future is more secure, and feel a quiet life. Meanwhile, factors traders are not interested in insurance is because they do not have enough money, the premium price is too expensive, distrust to the insurance company and feel have much savings. The level of legal awareness insured of traders categorized as good.
\end{abstract}

Keywords: legal awareness; insurance, traders, small and medium enterprises.

\section{Intisari}

Kesadaran hukum berasuransi di kalangan kaum pedagang sangat penting. Kesadaran hukum ibarat sebuah jembatan yang menghubungkan pedagang dengan hak dan kewajibannya. Para pedagang di Kota Medan tertarik berasuransi disebabkan oleh faktor bahwa risiko kerugian diambil alih oleh perusahaan asuransi, merasa aman dari bahaya, masa depan lebih terjamin, dan hidup lebih tenang. Faktor pedagang tidak tertarik berasuransi misalnya karena tidak memiliki cukup uang untuk membayar premi, harga premi yang terlalu mahal, ketidakpercayaan pada perusahaan asuransi, dan merasa punya banyak tabungan. Tingkat kesadaran hukum berasuransi para pedagang termasuk kategori baik.

Kata Kunci: kesadaran hukum, asuransi, pedagang, usaha kecil menengah.

\section{Pokok Muatan}

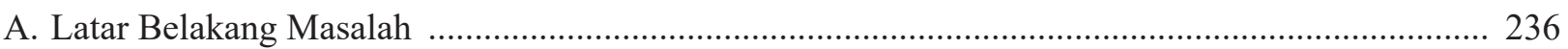

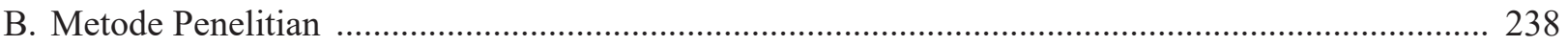

C. Hasil Penelitian dan Pembahasan ............................................................................................ 238

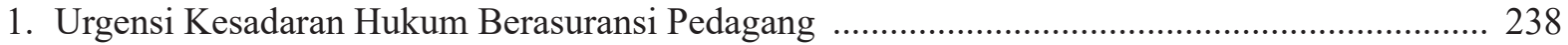

2. Faktor Penyebab Pedagang Tertarik Berasuransi ......................................................................... 239

3. Faktor Penyebab Pedagang Tidak Tertarik Berasuransi ....................................................... 240

4. Tingkat Kesadaran Hukum Berasuransi Pedagang di Lingkungan Pasar Kota Medan .............. 241

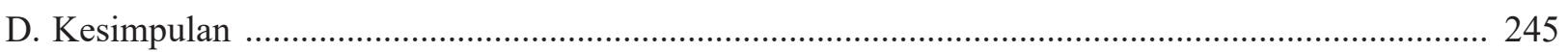

Hasil penelitian didanai oleh DRPM Direktorat Jenderal Penguatan Riset dan Pengembangan Kementerian Riset, Teknologi dan Pendidikan Tinggi. Penelitian dilakukan dalam rangka Hibah Penelitian Bersaing pada Tahun 2016.

** Alamat korespondensi: mulhadi_usu@yahoo.co.id.

*** Alamat korespondensi: zulfichairi@yahoo.co.id. 


\section{A. Latar Belakang Masalah}

Usaha Kecil dan Menengah (UKM) merupakan salah satu bagian penting dari perekonomian negara ataupun daerah. Kontribusi signifikan UKM terhadap out-put nasional atau Pendapatan Domestik Rerata Bruto (PDRB) sebesar $56,7 \%$, dan dalam ekspor non migas $15 \%$. UKM memberikan kontribusi sekitar 99\% dalam jumlah badan usaha Indonesia, serta mempunyai andil $99,6 \%$ dalam penyerapan tenaga kerja. ${ }^{1}$ Pada 2011, UKM mampu memberi andil besar terhadap penerimaan negara dengan menyumbang 61,9\% pemasukan PDRB melalui pembayaran pajak, (sektor usaha mikro menyumbang 36,28\% PDRB, sektor usaha kecil 10,9\%, dan sektor usaha menengah 14,7\%). Sementara itu, sektor usaha besar hanya menyumbang 38,1\% PDRB melalui pembayaran pajak. ${ }^{2}$ Bahkan menurut Bank Dunia, UKM termasuk usaha mikro (saat ini disebut UMKM), merupakan salah satu kekuatan pendorong terdepan dalam pembangunan ekonomi. Usaha ini memegang peranan yang cukup signifikan dalam perekonomian. Kontribusi pada penyerapan tenaga kerja misalnya, usaha jenis ini di Indonesia pada tahun 2007 mampu menyerap 77.678,498 ribu orang atau $96,77 \%$ dari total tenaga kerja. ${ }^{3}$

Masalah UKM saat ini yang menonjol adalah akses penyediaan pembiayaan usaha atau modal, keterbatasan infrastruktur dan akses pemerintah terkait dengan perizinan dan birokrasi serta tingginya tingkat pungutan. Dengan segala persoalan yang ada, potensi UKM yang besar itu menjadi terhambat. ${ }^{4}$ Namun masalah pelik lain yang dihadapi UKM adalah tingginya risiko yang mengancam eksistensi usaha setiap waktu karena rendahnya motivasi dan kesadaran hukum untuk memproteksi diri dan usahanya dengan asuransi. Di samping itu, sikap perusahaan asuransi yang belum sepenuhnya memberi akses pada UKM untuk mengalihkan risikonya pada perusahaan asuransi. Padahal asuransi memiliki tujuan mencegah dan/atau mengendalikan risiko sehingga eksistensi berusaha tetap bisa dipertahankan. Emmy Pangaribuan Simanjuntak bahkan menegaskan asuransi itu mempunyai tujuan utama mengalihkan risiko (tertanggung) yang ditimbulkan oleh peristiwa-peristiwa (yang tidak diharapkan terjadi) kepada orang lain (penanggung). ${ }^{5}$ Pendapat Emmy Pangaribuan masih selaras dengan tujuan asuransi yang tercantum pada bagian penjelasan umum Undang-Undang Nomor 40 Tahun 2014 tentang Perasuransian yang menyatakan bahwa asuransi bertujuan sebagai sarana pengelola risiko yang dibutuhkan masyarakat khususnya pelaku usaha. ${ }^{6}$

UKM yang melakukan aktivitas berdagang di lingkungan pasar kota merupakan pelaku usaha yang perlu mendapatkan perhatian, tidak hanya dalam bentuk dukungan atau pemberian akses permodalan tetapi juga akses informasi untuk bisa memproteksi diri dari risiko-risiko yang bisa setiap saat mengancam jiwa/raga dan kelangsungan usaha yang bersangkutan dalam bentuk asuransi. Pentingnya kalangan pedagang melindungi diri dan usahanya dari ancaman peristiwa yang tidak pasti tersebut, mengingat pasar adalah tempat yang mencakup banyak kegiatan, di mana di antara kegiatankegiatan tersebut bisa menjadi pemicu munculnya risiko seperti kebakaran, pencurian, perampokan, dan risiko lainnya yang terjadi dilingkungan toko (pasar). Risiko kebakaran misalnya, sangat berdam-

Teguh Sihono, "Usaha Kecil dan Menengah (UKM) dan Upaya Mengatasi Pengangguran”, Jurnal Ekonomia, Vol. 1, No. 1, Agustus 2005. Kontribusi PDRB UKM meningkat dari tahun ke tahun. Pada tahun 2010, PDRB UKM meningkat 0,59\% dari 56,53\% pada tahun 2009 menjadi $57,12 \%$ pada tahun 2010, sedangkan pada tahun 2011 meningkat sebesar $0,83 \%$ menjadi 57,94\% dan pada tahun 2012 terjadi peningkatan sebesar 1,14\% menjadi 59,08\%. Baca Anonim, "Kontribusi UKM Terhadap PDB Indonesia", http://iwansidharta.com/berita101-kontribusi-ukm-terhadap-pdb-indonesia.html, diakses 12 Maret 2015.

Badan Pusat Statistik, "Produk Domestik Bruto", http://www.bps.go.id/index.php?news=730, diakses 12 Maret 2015.

Y. Sri Susilo, "Peran Perbankan dalam Pembiayaan UMKM di Provinsi Daerah Istimewa Yogyakarta", Jurnal Keuangan dan Perbankan, Vol. 14 , No. 3, September 2010.

4 Sudaryanto, Ragimun dan Rahma Rina Wijayanti, "Strategi Pemberdayaan UMKM Menghadapi Pasar Bebas Asean", http://www.kemenkeu. go.id/sites/default/files/Strategi\%20Pemberdayaan\%20UMKM.pdf, hlm. 3, diakses 12 Maret 2015.

Djoko Prakoso dan I Ketut Murtika, 2004, Hukum Asuransi Indonesia, Rineka Cipta, Jakarta, hlm.8.

Penjelasan Umum Undang-Undang Nomor 40 Tahun 2014 tentang Perasuransian (Lembaran Negara Republik Indonesia Tahun 2014 Nomor 337, Tambahan Lembaran Negara Republik Indonesia Nomor 5618). 
pak atau merugikan, baik pada property milik pedagang maupun jiwa dan raga pedagang.

Pada tahun 2015, ada lebih kurang 7 (tujuh) peristiwa kebakaran pasar yang terjadi di Indonesia. Pada Januari 2015, Pasar Induk Tayu Pati-Jateng terbakar dengan taksiran kerugian 30 milyar rupiah. ${ }^{7}$ Pada Maret 2015, Pasar Induk Cikurubuk Tasikmalaya terbakar dengan kerugian 23,5 milyar rupiah. ${ }^{8}$ Dibulan yang sama juga menimpa 2 (dua) pasar seperti Pasar Raya Mekongga-Sulawesi Tengah $^{9}$ dan Pasar Tengah Bandar Lampung ${ }^{10}$ dengan taksiran kerugian milyaran rupiah. Kemudian pada bulan April 2015, terjadi lagi kebakaran yang menimpa Pasar Soreang BandungJabar, ${ }^{11}$ Pasar Ganefo Demak-Jateng, ${ }^{12}$ dan Pasar Siteba Padang-Sumbar. ${ }^{13}$

Kasus kebakaran pasar juga terjadi di kota Medan. Sepanjang tahun 2002 hingga tahun 2013 terdapat 9 (Sembilan) kasus kebakaran yang terjadi di beberapa pasar, di mana data kasus tersebut tersaji dalam tabel berikut ini.

Tabel 1.

Kebakaran Pasar di Kota Medan 2002-2013

\begin{tabular}{|c|c|c|c|c|c|}
\hline No. & $\begin{array}{l}\text { Waktu } \\
\text { Kejadian }\end{array}$ & $\begin{array}{l}\text { Nama Pasar/ } \\
\text { Wilayah }\end{array}$ & $\begin{array}{l}\text { Jumlah Ruko, Toko, } \\
\text { Kios Terbakar }\end{array}$ & $\begin{array}{l}\text { Taksiran } \\
\text { Kerugian (Rp) }\end{array}$ & Sumber Berita \\
\hline 1. & $20 / 9 / 2002$ & Pasar Petisah & 50 toko $\&$ kios & Milyaran & Tempo interaktif \\
\hline 2. & $13 / 6 / 2004$ & Pasar Brayan & 580 kios & Milyaran & Beritasore \\
\hline 3. & $17 / 9 / 2010$ & Pasar USU & 100 kios & 1 Milyar & Kompasiana \\
\hline 4. & $16 / 10 / 2010$ & Pasar Sukarame & 431 toko \& kios & Milyaran & MedanBisnis \\
\hline 5. & $10 / 10 / 2010$ & Pasar Sore & 100-an toko/kios & Milyaran & Okeone.com \\
\hline 6. & $18 / 1 / 2011$ & Pasar Brayan & 600 kios & 5 Milyar & Beritasore \\
\hline 7. & $15 / 10 / 2012$ & Pasar Helvetia & 50 kios & Ratusan Juta & Kompas.com \\
\hline 8. & $23 / 10 / 2012$ & Pasar Sambu & 13 ruko dan 890 kios & Milyaran & MedanBisnis \\
\hline 9. & $6 / 1 / 2013$ & Pasar Besi & $\begin{array}{l}18 \text { bangunan, kios, } \\
\text { rumah dan stand }\end{array}$ & Ratusan Juta & Terasmedan.com \\
\hline
\end{tabular}

Sumber: Diolah Penulis, 2016.

Berdasarkan latar belakang masalah pedagang di lingkungan Pasar Kota Medan tertarik sebagaimana dijelaskan di atas, terdapat (empat) berasuransi atau menutup polis asuransi?; (3) rumusan masalah yang hendak ditindaklanjuti Faktor-faktor apa saja yang menjadi penyebab para dalam penelitian ini, yaitu: (1) Bagaimana urgensi pedagang di lingkungan Pasar Kota Medan tidak kesadaran hukum berasuransi bagi pedagang sebagai tertarik berasuransi atau menutup polis asuransi?; kelompok Usaha Kecil Menengah (UKM)?; (2) dan (4) Bagaimana tingkat kesadaran hukum Faktor-faktor apa saja yang menjadi penyebab para berasuransi di kalangan pedagang di lingkungan

Semarang Bisnis, "Kebakaran Pasar Tayu, Kerugian Sementara Rp30 Miliar", http://semarang.bisnis.com/read/20150129/1/76378/ kebakaran-pasar-tayu-kerugian-sementara-rp30-miliar, diakses tanggal 12 April 2015.

8 Tribun Jabar, "Kebakaran Pasar Cikurubuk Telan Kerugian Sekitar Rp 23,5 M", http://jabar.tribunnews.com/2015/03/18/kebakaran-pasarcikurubuk-telan-kerugian-sekitar-rp-235-m, diakses tanggal 15 April 2015.

9 Darwis Sarkani, "Pasar Raya Mekongga Kolaka Terbakar", http://antarasultra.com/berita/277450/pasar-raya-mekongga-kolaka-terbakar, diakses 15 April 2015.

10 Tribun Lampung, "Si Jago Merah Lalap Ruko di Pasar Tengah”, http://lampung.tribunnews.com/2015/03/30/breaking-news-si-jago-merahlalap-ruko-di-pasar-tengah, diakses 15 April 2015.

11 Bayu Hermawan, "Pasar Soreang Bandung Terbakar", http://nasional.republika.co.id/berita/nasional/daerah/15/04/10/nmlctt-pasar-soreangbandung-terbakar, diakses 15 April 2015.

12 Andik Sismanto, "Lima Kios di Pasar Ganefo Demak Ludes Terbakar", https://daerah.sindonews.com/read/988860/22/lima-kios-di-pasarganefo-demak-ludes-terbakar-1428931753, diakses 15 April 2015.

13 Sumbar Satu, "Kebakaran di Pasar Siteba Padang, Tiga Meninggal Terpanggang", http://www.sumbarsatu.com/berita/10013-kebakaran-dipasar-siteba-padang-tiga-meninggal-terpanggang, diakses 15 April 2015. 
pasar Kota Medan?

\section{B. Metode Penelitian}

Penelitian ini dilakukan di Kota Medan Provinsi Sumatera Utara dengan pendekatan yuridis empiris dengan mengandalkan data primer dari lapangan dengan cara menyiapkan kuesioner/angket langsung dan berstruktur. ${ }^{14}$ Populasi penelitian ini adalah para pedagang di lingkungan pasar Kota Medan, di mana sampel ditentukan dengan teknik purposive/judgement sampling ${ }^{15}$ dengan menyebarkan kuesioner kepada 95 (sembilan puluh lima) orang responden pedagang di beberapa pasar utama yang pernah mengalami kebakaran, seperti Pasar Brayan, Pasar Helvetia, Pasar Petisah, dan Pasar Sukarame. Instrumen kuesioner/angket diukur dengan menggunakan skala likert 5 poin. ${ }^{16}$ Data kemudian dianalisis secara kuantitatif yakni dengan analisis deskriptif persentase $(\mathrm{P}=\mathrm{f} / \mathrm{Nx} 100 \%)$.

\section{Hasil Penelitian dan Pembahasan}

1. Urgensi Kesadaran Hukum Berasuransi Pedagang

Konsep mengenai apa itu kesadaran meruzpakan konsep yang membingungkan dalam ilmu pengetahuan. Salah satu penyebabnya adalah karena pengertian kesadaran sangat bervariasi sehingga tidak ada satu pengertian umum yang dapat diterima semua kalangan. Kesadaran dalam kamus bahasa Indonesia berarti keadaan mengerti akan sesuatu. Menurut Kainth mendefinisikan kesadaran sebagai kepemilikan pengetahuan atau menjadi sadar akan seseorang, situasi atau sesuatu. ${ }^{17}$ Widjaya mengemukakan bahwa sadar (kesadaran) itu adalah kesadaran kehendak dan kesadaran hukum. Sadar diartikan merasa, tahu, ingat akan keadaan sebenarnya dan ingat keadaan dirinya.
Kesadaran diartikan sebagai keadaan tahu, mengerti dan merasa, misalnya tentang harga diri, kehendak hukum dan lainnya. ${ }^{18}$

Kesadaran hukum menurut kamus besar bahasa Indonesia adalah kesadaran seseorang akan pengetahuan bahwa suatu perilaku tertentu diatur oleh hukum. Kesadaran hukum pada titik tertentu diharapkan mampu untuk mendorong seseorang mematuhi dan melaksanakan atau tidak melaksanakan apa yang dilarang dan atau apa yang diperintahkan oleh hukum. Oleh karena itu, peningkatan kesadaran hukum merupakan salah satu bagian penting dalam upaya untuk mewujudkan penegakan hukum.

Mengacu pada Peraturan Menteri Hukum dan Hak Asasi Manusia RI Nomor M.01-PR.08.10 Tahun 2006 Tentang Pola Penyuluhan Hukum, Pasal 1 angka 1 menyebutkan kesadaran hukum masyarakat adalah nilai yang hidup dalam masyarakat, sebagai bentuk pemahaman dan ketaatan atau kepatuhan masyarakat terhadap norma hukum dan peraturan perundang-undangan yang berlaku. Kesadaran hukum bahkan merupakan faktor dalam penemuan hukum. Tidak itu saja, Krabbe mengatakan bahwa sumber segala hukum adalah kesadaran hukum. Tentu hukum yang dimaksud di sini adalah hukum yang memenuhi kesadaran hukum kebanyakan orang. Oleh karenanya, undang-undang yang tidak sesuai dengan kesadaran hukum kebanyakan orang akan kehilangan kekuatan mengikatnya. ${ }^{19}$

Kesadaran/sadar hukum, adalah suatu kondisi di mana masyarakat mau menghargai, mau mematuhi hukum dengan kesadaran sendiri, tanpa adanya suatu paksaan dari siapa pun. Secara sederhana kesadaran hukum masyarakat pada hakikatnya adalah merupakan basis aktivitas sosial agar produk hukum yang dihasilkan dapat benar-

\footnotetext{
4 Kartini Kartono, 1996, Pengantar Metodologi Riset Sosial, Mandar Maju, Bandung, hlm. 224-225. Baca juga Sugiyono, 2012, Metode Penelitian Pendidikan Pendekatan Kuantitatif, Kualitatif, dan R\&D, ALFABETA, Bandung, hlm.193-194.

Ulber Silalahi, 1999, Metode dan Metodologi Penelitian, Bina Budhaya, Bandung, hlm. 214.

Ibid., hlm.171.

17 Gursharan Singh Kainth, "Environmental Awareness Among School Teachers The Icfai", University Journal of Environmental Economics, Vol. VII, No. 1. 2009, hlm. 34-50.

Widjaya, 1984, Kesadaran Hukum Manusia dan Manusia Pancasila, Era Swasta, Jakarta, hlm.14.

19 Sudikno Mertokusumo, "Meningkatkan Kesadaran Hukum Masyarakat", Makalah, disampaikan dalam Rangka Kerjasama Kampanye Penegakan Hukum antara Fakultas Hukum UGM dengan Kejaksaan Agung RI, Yogyakarta 29 Juli 1978, hlm.1.
} 
benar ditaati dalam kehidupan sehari-hari, dan dijadikan acuan perilaku oleh warga masyarakat. ${ }^{20}$

Beni Ahmad Saebeni juga menyatakan pendapatnya, kesadaran hukum artinya keadaan ikhlas yang muncul dari hati nurani dalam mengakui dan mengamalkan sesuatu sesuai dengan tuntunan yang terdapat di dalamnya, yang muncul dari hati nurani dan jiwa yang terdalam dari manusia sebagai individu atau masyarakat untuk melaksanakan pesan-pesan yang terdapat dalam hukum. ${ }^{21}$ Kesadaran hukum masyarakat adalah merupakan keluaran (output) dari proses kegiatan penyuluhan yang mencapai tingkat optimalisasi ideal yang ditandai dengan timbulnya rasa untuk menghargai hukum, maka secara hipotesis, bahwa hanya cara atau teknik penyuluhan yang komunikatif dan mampu menyentuh hati nurani warga masyarakat untuk menghargai hukum, yang dapat efektif untuk menimbulkan kesadaran hukum masyarakat. ${ }^{22}$

Merujuk pada pandangan di atas, kesadaran hukum masyarakat seperti kaum pedagang, sangat ditentukan oleh sejauh mana kaum pedagang memutuskan pilihannya dalam rangka olah pemikiran untuk berbuat atau berperilaku, mematuhi norma hukum atau tidak. Untuk sampai pada jawaban permasalahan ini perlu dipahami juga tentang bagaimana orang/warga masyarakat mendefinisikan dan mempunyai pemahaman atau memberi makna terhadap hukum, serta bagaimana secara psikologis orang/warga masyarakat memberikan penilaian terhadap hukum. ${ }^{23}$

Kesadaran hukum berasuransi di kalangan kaum pedagang sangatpenting, mengingatkesadaran hukum ibaratsebuah jembatan yang menghubungkan kaum pedagang dengan hak-hak dan kewajibannya. Adanya pengetahuan dan pemahaman hukum yang baik di kalangan kaum pedagang sebagai kelompok UKM di tengah masyarakat, akan mengantarkan mereka pada pola perilaku/sikap hukum untuk mematuhi dan mewujudkan isi hukum berupa hak dan kewajiban mereka sebagai salah satu subjek hukum dalam industri perasuransian. Rendahnya kesadaran hukum tentu akan membawa mereka (kaum pedagang) pada perlakuan yang tidak sesuai hukum-yang melanggar hak-hak mereka sebagai subjek hukum yang semestinya dilindungi menurut peraturan perundang-undangan yang berlaku.

\section{Faktor Penyebab Pedagang Tertarik Berasuransi}

Berdasarkan penelitian yang dilakukan di beberapa pasar utama di Kota Medan, yakni Pasar Brayan, Pasar Helvetia, Pasar Petisah, dan Pasar Sukarame, menunjukkan adanya beberapa alasan atau faktor yang mendorong para pedagang tertarik membeli asuransi. Faktor atau alasan pertama yang dikemukakan oleh para pedagang sehingga mereka mau berasuransi adalah agar risiko kerugian yang dialami para pedagang diambil alih (ditanggung) oleh perusahaan asuransi (14 responden) atau 14,7\%. Faktor atau alasan kedua dan ketiga, agar pedagang merasa aman dari bahaya dan masa depan lebih terjamin dengan adanya uang ganti kerugian yang diberikan oleh perusahaan asuransi (masingmasing 11 responden) atau 11,6\%. Alasan keempat dan kelima, agar pedagang (tertanggung) bisa hidup lebih tenang dan kesehatan lebih terjamin (masing-masing 9 \%). Alasan keenam, karena pedagang yang bersangkutan mampu membayar premi sehingga tertarik berasuransi ( 8 responden atau 8,4\%). Alasan ketujuh, agar pendidikan anak terjamin $(7,4 \%)$. Sedangkan alasan terakhir menurut responden adalah agar harta tidak hilang $(2,1 \%)$.

Sayangnya, dari jumlah responden sebanyak 95 orang, terdapat 24 responden yang tidak memberikan jawaban apa-apa yang persentasenya cukup besar yakni 25,3\%. Menurut peneliti, ketidakmampuan responden menentukan jawaban karena pengetahuan dan pemahaman mengenai

\footnotetext{
Tana Mantiri (Ed), 2011, Dampak Penyuluhan Hukum terhadap Tingkat Kesadaran Hukum Masyarakat, BPHN-Kementerian Hukum dan Hak Asasi Manusia Republik Indonesia, Jakarta, hlm.19.

Beni Ahmad Saebeni, 2006, Sosiologi Hukum, Pustaka Setia, Bandung, hlm. 197.

Tana Mantiri (Ed), Op.cit., hlm.12.

Ibid., hlm.19.
} 
hukum asuransi yang masih sangat terbatas.

Tabel 2.

Rekapitulasi Alasan Pedagang di 4 Pasar Kota Medan Tertarik Membeli Asuransi

\begin{tabular}{lcc}
\hline Kriteria & Frekuensi & Persentase \\
\hline Tidak dijawab & 24 & 25,3 \\
\hline Karena mampu membayar premi & 8 & 8,4 \\
\hline Agar hidup tenang & 9 & 9,5 \\
\hline Agar aman dari bahaya & 11 & 11,6 \\
\hline Agar risiko kerugian ditanggung asuransi & 14 & 14,7 \\
\hline Agar kehidupan di masa depan terjamin & 11 & 11,6 \\
\hline Agar harta tidak hilang & 2 & 2,1 \\
\hline Agar kesehatan terjamin & 9 & 9,5 \\
\hline Agar pendidikan anak terjamin & 7 & 7,4 \\
\hline Total & $\mathbf{9 5}$ & $\mathbf{1 0 0 , 0}$ \\
\hline
\end{tabular}

Sumber: Diolah Penulis, 2016.

\section{Faktor Penyebab Pedagang Tidak Tertarik Berasuransi}

Berdasarkan hasil olahan data kuesioner yang disebar di 4 (empat) pasar utama di Kota Medan, ditemukan adanya beberapa faktor yang menyebabkan para pedagang enggan (tidak tertarik) untuk membeli polis asuransi. Faktor yang paling menonjol adalah alasan tidak punya uang untuk membayar iuran/premi $(27,4 \%)$, harga premi yang terlalu mahal $(12,6 \%)$, alasan tidak percayanya mereka (pedagang) pada perusahaan asuransi (12,6\%). Ada juga beberapa responden menyatakan ketidaktertarikan berasuransi disebabkan karena tidak ingin berurusan dengan asuransi dan perusahaan asuransi $(6,3 \%)$, merasa aman tanpa asuransi $(5,3 \%)$ dan merasa mampu mengatasi masalah sendiri sehingga tidak perlu ada asuransi (3\%). Sedangkan alasan lainnya karena merasa punya banyak tabungan $(1,1 \%)$, trauma dengan asuransi $(1,1 \%)$ dan adanya keyakinan yang penuh pada takdir dan pertolongan Tuhan $((1,1 \%)$. Sayangnya dalam kaitannya dengan pertanyaan ini terdapat $29,5 \%$ responden tidak memberikan pendapatnya.

Tabel 3.

Rekapitulasi Alasan Pedagang di 4 Pasar Kota Medan Tidak Membeli Polis Asuransi

\begin{tabular}{lcc}
\hline Kriteria & Frekuensi & Persentase \\
\hline tidak dijawab & 28 & 29,5 \\
\hline tidak punya uang untuk bayar premi & 26 & 27,4 \\
\hline harga premi terlalu mahal & 12 & 12,6 \\
\hline punya banyak tabungan & 1 & 1,1 \\
\hline merasa aman tanpa asuransi & 5 & 5,3 \\
\hline merasa mampu mengatasi masalah sendiri & 3 & 3,2 \\
\hline tidak mau ada urusan dengan asuransi & 6 & 6,3 \\
\hline tidak percaya dengan asuransi & 12 & 12,6 \\
\hline trauma dengan asuransi & 1 & 1,1 \\
\hline yakin pada takdir dan pertolongan tuhan & 1 & 1,1 \\
\hline Total & $\mathbf{9 5}$ & $\mathbf{1 0 0 , 0}$ \\
\hline
\end{tabular}

Sumber: Diolah Penulis, 2016. 
4. Tingkat Kesadaran Hukum Berasuransi Pedagang di Lingkungan Pasar Kota Medan

Keingintahuan untuk mengungkap tingkat kesadaran hukum berasuransi para pedagang di lingkungan pasar Kota Medan dilakukan dengan cara mengajukan beberapa pertanyaan berkenaan dengan hukum asuransi yang meliputi pengetahuan, pemahaman, dan sikap/perilaku hukum dari para pedagang. Instrumen kuesioner diukur dengan menggunakan skala likert 5 poin.

Tabel 4.

Bobot dan Persentase Nilai Skala Likert 5 Poin

\begin{tabular}{llll}
\hline Kriteria \& Bobot Nilai & Persentase & Keterangan \\
\hline ST/SP & 5 & $80 \%-100 \%$ & Sangat Tinggi/Sangat Baik \\
\hline T/P & 4 & $60 \%-79,99 \%$ & Tinggi/Baik \\
\hline N & 3 & $40 \%-59,99 \%$ & Cukup Tinggi/Cukup Baik \\
\hline TT/TP & 2 & $20 \%-39,99 \%$ & Rendah/Tidak Baik \\
\hline STT/STP & 1 & $0 \%-19,99 \%$ & Sangat Rendah/Sangat Tidak Baik \\
\hline
\end{tabular}

Sumber: Diolah Penulis, 2016.

Keterangan:
$\mathrm{ST} / \mathrm{SP}=$ Sangat Tahu $/$ Sangat Paham
$\mathrm{T} / \mathrm{P} \quad=$ Tahu $/$ Paham
$\mathrm{N} \quad=$ Netral
TT/TP $=$ Tidak Tahu / Tidak Paham
STT $/$ STP $=$ Sangat Tidak Tahu $/$ Sangat Tidak Paham

\section{a. Pengetahuan Hukum Asuransi Pedagang}

Tabel 5.

Pengetahuan Hukum Asuransi Pedagang di 4 Pasar Kota Medan

\begin{tabular}{|c|c|c|c|c|c|c|c|c|c|c|}
\hline \multirow{3}{*}{$\begin{array}{l}\text { Pertanyaan tentang } \\
\text { Pengetahuan } \\
\text { Hukum Asuransi }\end{array}$} & \multicolumn{10}{|c|}{ Frekuensi } \\
\hline & \multicolumn{2}{|c|}{$\begin{array}{l}\text { Sangat } \\
\text { Rendah }\end{array}$} & \multicolumn{2}{|c|}{ Rendah } & \multicolumn{2}{|c|}{ Cukup } & \multicolumn{2}{|c|}{ Tinggi } & \multicolumn{2}{|c|}{$\begin{array}{l}\text { Sangat } \\
\text { Tinggi }\end{array}$} \\
\hline & $\begin{array}{l}\text { Jlh } \\
\text { Skor }\end{array}$ & $\begin{array}{c}\text { Index } \\
\%\end{array}$ & $\begin{array}{l}\text { Jlh } \\
\text { Skor }\end{array}$ & $\begin{array}{l}\text { Index } \\
\%\end{array}$ & $\begin{array}{l}\text { Jlh } \\
\text { Skor }\end{array}$ & $\begin{array}{c}\text { Index } \\
\%\end{array}$ & $\begin{array}{l}\text { Jlh } \\
\text { Skor }\end{array}$ & $\begin{array}{c}\text { Index } \\
\%\end{array}$ & $\begin{array}{l}\text { Jlh } \\
\text { Skor }\end{array}$ & $\begin{array}{c}\text { Index } \\
\%\end{array}$ \\
\hline Istilah Asuransi & - & - & - & - & - & - & 364 & 76,63 & - & - \\
\hline UU Asuransi & - & - & - & - & - & - & 304 & 64 & - & - \\
\hline UU No.40/2014 & - & - & - & - & 217 & 45,68 & - & - & - & - \\
\hline $\begin{array}{l}\text { Perjanjian Asuransi } \\
\text { disebut polis }\end{array}$ & - & - & - & - & - & - & 298 & 62,73 & - & - \\
\hline $\begin{array}{l}\text { Pemegang Polis disebut } \\
\text { Tertanggung }\end{array}$ & - & - & - & - & - & - & 316 & 66,52 & - & - \\
\hline $\begin{array}{l}\text { Perusahaan Asuransi } \\
\text { disebut Penanggung }\end{array}$ & - & - & - & - & - & - & 322 & 67,78 & - & - \\
\hline $\begin{array}{l}\text { Asuransi secara umum } \\
\text { adalah asuransi jiwa } \\
\text { dan kerugian }\end{array}$ & - & - & - & - & - & - & 326 & 68,63 & - & - \\
\hline
\end{tabular}

Sumber: Diolah Penulis, 2016. 
Berdasarkan tabel di atas, secara umum dapat disimpulkan bahwa tingkat pengetahuan hukum asuransi responden atau para pedagang di 4 pasar di Kota Medan adalah tinggi/baik, dengan total skor tertinggi ditunjukkan dari pengetahuan istilah asuransi sebesar 364 (76,63\%). Namun, ketika ditanya Undang-Undang Nomor 40 Tahun 2014 sebagai peraturan tentang perasuransian saat ini para responden hanya memiliki pengetahuan yang cukup yakni dengan skor 217 atau 45,68\%.

\section{b. Pemahaman Hukum Asuransi Pedagang}

Peneliti mengajukan lebih kurang 15 (lima belas) pertanyaan untuk mengetahui pemahaman Hukum Asuransi di kalangan pedagang di Kota Medan. Pertanyaan-pertanyaan tersebut erat kaitannya dengan manfaat dan tujuan asuransi. Tidak ada persoalan berkenaan dengan pertanyaanpertanyaan sebagaimana dimaksud di atas, sehingga jawaban para pedagang secara garis besar menunjukkan skor yang tinggi. Dengan kata lain, dapat disimpulkan bahwa pemahaman Hukum Asuransi di kalangan para pedagang di 4 pasar utama di Kota Medang tinggi. Hal tersebut ditunjukkan melalui tabel di bawah ini.

Tabel 6.

Pemahaman Hukum Asuransi Pedagang di 4 Pasar Kota Medan

\begin{tabular}{|c|c|c|c|c|c|c|c|c|c|c|}
\hline \multirow{3}{*}{$\begin{array}{l}\text { Pertanyaan } \\
\text { tentang } \\
\text { Pemahaman } \\
\text { Hukum Asuransi }\end{array}$} & \multicolumn{10}{|c|}{ Frekuensi } \\
\hline & \multicolumn{2}{|c|}{$\begin{array}{l}\text { Sangat } \\
\text { Rendah }\end{array}$} & \multicolumn{2}{|c|}{ Rendah } & \multicolumn{2}{|c|}{ Cukup } & \multicolumn{2}{|c|}{ Tinggi } & \multicolumn{2}{|c|}{ Sangat Tinggi } \\
\hline & $\begin{array}{l}\text { Jlh } \\
\text { Skor }\end{array}$ & $\begin{array}{c}\text { Index } \\
\%\end{array}$ & $\begin{array}{l}\text { Jlh } \\
\text { Skor }\end{array}$ & $\begin{array}{c}\text { Index } \\
\%\end{array}$ & $\begin{array}{l}\text { Jlh } \\
\text { Skor }\end{array}$ & $\begin{array}{c}\text { Index } \\
\%\end{array}$ & $\begin{array}{l}\text { Jlh } \\
\text { Skor }\end{array}$ & $\begin{array}{c}\text { Index } \\
\%\end{array}$ & $\begin{array}{l}\text { Jlh } \\
\text { Skor }\end{array}$ & $\begin{array}{c}\text { Index } \\
\%\end{array}$ \\
\hline $\begin{array}{l}\text { Asuransi dimulai } \\
\text { dengan perjanjian }\end{array}$ & - & - & - & - & - & - & 337 & 70,94 & - & - \\
\hline $\begin{array}{l}\text { Kewajiban } \\
\text { Tertanggung } \\
\text { Membayar Premi }\end{array}$ & - & - & - & - & - & - & 335 & 70,52 & - & - \\
\hline $\begin{array}{l}\text { Harta Benda dan } \\
\text { Jiwa dapat Diancam } \\
\text { Bahaya }\end{array}$ & - & - & - & - & - & - & 358 & 75,36 & - & - \\
\hline $\begin{array}{l}\text { Asuransi dapat } \\
\text { Menanggulangi } \\
\text { Risiko Tertanggung }\end{array}$ & - & - & - & - & - & - & 328 & 69,26 & - & - \\
\hline $\begin{array}{l}\text { Asuransi Menjamin } \\
\text { Eksistensi Usaha }\end{array}$ & - & - & - & - & - & - & 343 & 72,21 & - & - \\
\hline $\begin{array}{l}\text { Asuransi Memberi } \\
\text { Rasa Aman pada } \\
\text { Tertanggung \& } \\
\text { Keluarga }\end{array}$ & - & - & - & - & - & - & 338 & 71,15 & - & - \\
\hline $\begin{array}{l}\text { Asuransi Menjamin } \\
\text { Masa Depan Anak } \\
\text { di Masa Datang }\end{array}$ & - & - & - & - & - & - & 347 & 73,05 & - & - \\
\hline $\begin{array}{l}\text { Asuransi menjamin } \\
\text { kehidupan ahli } \\
\text { waris yang } \\
\text { ditinggalkan }\end{array}$ & - & - & - & - & - & - & 335 & 70,52 & - & - \\
\hline
\end{tabular}




\begin{tabular}{|c|c|c|c|c|c|c|c|c|c|c|}
\hline $\begin{array}{l}\text { Perusahaan asuransi } \\
\text { tidak membayar } \\
\text { klaim (uang } \\
\text { asuransi) jika } \\
\text { premi tidak dibayar } \\
\text { tertanggung }\end{array}$ & - & - & - & - & - & - & 315 & 66,32 & - & - \\
\hline $\begin{array}{l}\text { Kejujuran } \\
\text { tertanggung } \\
\text { merupakan hal } \\
\text { penting dalam } \\
\text { perjanjian asuransi }\end{array}$ & - & - & - & - & - & - & 302 & 63,57 & - & - \\
\hline $\begin{array}{l}\text { Asuransi Kerugian } \\
\text { Hanya Menanggung } \\
\text { Sebesar Kerugian } \\
\text { yang Diderita }\end{array}$ & - & - & - & - & - & - & 304 & 64 & - & - \\
\hline $\begin{array}{l}\text { Asuransi tidak } \\
\text { Bisa Dijadikan } \\
\text { Sarana Mencari } \\
\text { Keuntungan } \\
\text { Berlipat Ganda } \\
\end{array}$ & - & - & - & - & - & - & 321 & 67,57 & - & - \\
\hline $\begin{array}{l}\text { Tujuan Asuransi } \\
\text { Jiwa memberi } \\
\text { pertanggungan bagi } \\
\text { jiwa seseorang }\end{array}$ & - & - & - & - & - & - & 325 & 68,42 & - & - \\
\hline $\begin{array}{l}\text { Tujuan Asuransi } \\
\text { Kebakaran } \\
\text { menjamin } \\
\text { kehilangan atau } \\
\text { kerusakan harta } \\
\text { benda }\end{array}$ & - & - & - & - & - & - & 322 & 67,78 & - & - \\
\hline $\begin{array}{l}\text { Kebakaran terhadap } \\
\text { ruko/toko/kios } \\
\text { menyebabkan } \\
\text { kerugian bagi } \\
\text { pemiliknya }\end{array}$ & - & - & - & - & - & - & 349 & 73,47 & - & - \\
\hline
\end{tabular}

Sumber: Diolah Penulis, 2016.

\section{c. Perilaku Hukum Asuransi Pedagang}

Salah satu bagian penting yang tidak bisa diabaikan dalam mengukur tingkat kesadaran hukum satu kelompok masyarakat adalah perilaku atau budaya hukumnya. Walaupun demikian, peneliti mengalami kesulitan untuk mengukur tingkat perilaku/budaya hukum kelompok masyarakat ini (pedagang).

Berkenaan dengan perilaku Hukum Asuransi para Pedagang di 4 Pasar Utama Kota Medan, peneliti juga mengajukan beberapa pertanyaan. Misalnya tentang apakah responden pernah/tidaknya ditawari polis asuransi; punya/tidak polis asuransi; pihak yang pertama kali menawari responden untuk membeli polis asuransi? Apakah anggota keluarga termasuk orang-orang yang juga memiliki polis; dan jenis polis asuransi yang dimiliki oleh responden?

Pada saat ditanyakan kepada responden (pedagang) pernah/tidak ditawari polis asuransi oleh seseorang/perusahaan: 
Tabel 7.

Pernah/Tidaknya Ditawari Polis Asuransi

\begin{tabular}{lcc}
\hline Kriteria Jawaban & Frekuensi & Persentase \\
\hline tidak dijawab & 3 & 3,2 \\
\hline pernah & 79 & 83,2 \\
\hline belum pernah & 13 & 13,7 \\
\hline Total & $\mathbf{9 5}$ & $\mathbf{1 0 0 , 0}$ \\
\hline
\end{tabular}

Sumber: Diolah Penulis, 2016.

Ketika kepada responden ditanyakan apakah saat ini di rumah masing-masing (para responden) memiliki lembar polis (kontrak asuransi)?

Lebih dari separuh responden menyatakan bahwa mereka mempunyai/memiliki polis asuransi (50,5\%). Sisanya 42,1\% menyatakan tidak mempunyai/memiliki polis, dan 7,4\% tidak menjawab.

Tabel 8.

\section{Kepemilikan Polis}

\begin{tabular}{lcc}
\hline Kriteria & Frekuensi & Persentase \\
\hline tidak dijawab & 7 & 7,4 \\
\hline punya & 48 & 50,5 \\
\hline tidak punya & 40 & 42,1 \\
\hline Total & $\mathbf{9 5}$ & $\mathbf{1 0 0 , 0}$ \\
\hline
\end{tabular}

Sumber: Diolah Penulis, 2016.

Kepada para responden juga ditanyakan pihak mana pertama kali yang menawari mereka asuransi atau polis asuransi? Lebih separuh atau $50,5 \%$ responden menyatakan bahwa mereka ditawari oleh agen asuransi. 24,2\% melalui sahabat/ teman, dan $11,6 \%$ ditawari oleh saudara. Sedangkan sisanya $13,7 \%$ tidak menyatakan pendapatnya.

Tabel 9.

Pihak yang Menawari Polis Asuransi Pertama Kali

\begin{tabular}{lcc}
\hline Kriteria & Frekuensi & Persentase \\
\hline tidak dijawab & 13 & 13,7 \\
\hline teman & 23 & 24,2 \\
\hline saudara & 11 & 11,6 \\
\hline agen & 48 & 50,5 \\
\hline Total & $\mathbf{9 5}$ & $\mathbf{1 0 0 , 0}$ \\
\hline
\end{tabular}

Sumber: Diolah Penulis, 2016.
Peneliti berkeyakinan bahwa salah satu faktor yang menyebabkan seseorang melakukan satu perbuatan tertentu seperti berasuransi, adalah faktor lingkungan, khususnya keluarga. Oleh karena itu, pengaruh keluarga terhadap minat berasuransi responden juga menjadi perhatian peneliti. Dalam tabel 10 di bawah ini ternyata $56,8 \%$ anggota keluarga responden memiliki Polis Asuransi.

Tabel 10.

\section{Kepemilikan Anggota Keluarga Lain atas Polis Asuransi}

\begin{tabular}{lcc}
\hline Kriteria & Frekuensi & Persentase \\
\hline tidak dijawab & 8 & 8,4 \\
\hline ya & 54 & 56,8 \\
\hline tidak & 33 & 34,8 \\
\hline Total & $\mathbf{9 5}$ & $\mathbf{1 0 0 , 0}$ \\
\hline
\end{tabular}

Sumber: Diolah Penulis, 2016.

Hal penting yang ditemukanmelaluipenelitian ini adalah rendahnya keinginan kaum pedagang untuk mengasuransikan barang dagangan atau harta miliknya (property), pada perusahaan Asuransi Kerugian. Bila data lapangan menunjukkan bahwa pengetahuan dan pemahaman Hukum Asuransi responden masuk kategori tinggi/baik, namun berbanding terbalik pada tingkat aplikasi, di mana perilaku atau budaya hukumnya khususnya untuk Asuransi Kerugian seperti Asuransi Kebakaran Ruko, Toko atau Kios ternyata cukup rendah. Hal ini bisa diperhatikan dalam tabel 11, di mana hanya 28 responden atau $29,5 \%$ yang mengaku memiliki Asuransi Jiwa; 12 responden (12,6\%) memiliki Asuransi Sosial; 11 responden (11,6\%) yang memiliki Asuransi Kesehatan; 5 responden (5,3\%) yang memiliki Asuransi Pendidikan; 4 responden (4,2\%) mengaku memiliki Asuransi Kebakaran Toko/Kios; dan hanya 2 responden $(2,1 \%)$ yang menyatakan punya semua jenis asuransi, baik Asuransi Jiwa, Asuransi Kendaraan.

Walaupun para responden dalam tabel 6 memiliki pemahaman yang baik/tinggi tentang tujuan Asuransi Kebakaran khususnya kebakaran ruko/toko/kios beserta akibat yang ditimbulkannya, 
namun pada kenyataannya hanya 4 responden (4,2\%) yang memiliki Asuransi Kebakaran ruko/ toko/kios.

Tabel 11.

\section{Jenis Polis Asuransi yang Dimiliki}

\begin{tabular}{lcc}
\hline Kriteria & Frekuensi & Persentase \\
\hline tidak dijawab & 32 & 33,7 \\
\hline asuransi jiwa & 28 & 29,5 \\
\hline asuransi kendaraan & 1 & 1,1 \\
\hline $\begin{array}{l}\text { asuransi kebakaran } \\
\text { ruko/toko/kios }\end{array}$ & 4 & 4,2 \\
\hline asuransi sosial & 12 & 12,6 \\
\hline asuransi kesehatan & 11 & 11,6 \\
\hline asuransi pendidikan & 5 & 5,3 \\
\hline semua asuransi & 2 & 2,1 \\
\hline Total & $\mathbf{9 5}$ & $\mathbf{1 0 0 , 0}$ \\
\hline
\end{tabular}

Sumber: Diolah Penulis, 2016.

Hal terakhir yang ditanyakan kepada responden yang berkaitan dengan perilaku/budaya hukum yang pernah dilakukan adalah pilihan tempat pembayaran dan pengajuan klaim asuransi. Sebanyak 44,2\% responden memilih bank sebagai tempat pembayaran premi, $40,0 \%$ memilih kantor asuransi, 9,5\% memilih pembayaran pada agen asuransi, dan sisanya 6,3\% tidak menjawab. Sedangkan tempat pengajuan klaim asuransi ketika risiko terjadi, responden menyatakan bahwa pengajuan klaim dilakukan pada kantor asuransi (84\%), dan agen asuransi $(15,8 \%)$.

\section{Kesimpulan}

Kesadaran hukum berasuransi di kalangan kaum pedagang sangatpenting, mengingat kesadaran hukum ibarat sebuah jembatan yang menghubungkan kaum pedagang dengan hak-hak dan kewajibannya. Adanya pengetahuan dan pemahaman hukum yang baik di kalangan kaum pedagang sebagai kelompok UKM di tengah masyarakat, akan mengantarkan mereka pada pola perilaku (sikap) hukum untuk mematuhi dan mewujudkan isi hukum berupa hak dan kewajiban mereka sebagai salah satu subjek hukum dalam industri perasuransian. Rendahnya kesadaran hukum tentu akan membawa mereka (kaum pedagang) pada perlakuan yang tidak sesuai hukum, yang melanggar hak-hak mereka sebagai subjek hukum yang semestinya dilindungi menurut peraturan perundang-undangan yang berlaku.

Faktor atau alasan pertama yang dikemukakan oleh para pedagang sehingga mereka mau berasuransi adalah agar risiko kerugian yang dialami para pedagang diambil alih (ditanggung) oleh perusahaan asuransi (14 responden) atau $14,7 \%$. Faktor atau alasan kedua dan ketiga, agar pedagang merasa aman dari bahaya dan masa depan lebih terjamin dengan adanya uang ganti kerugian yang diberikan oleh perusahaan asuransi (masingmasing 11 responden) atau 11,6\%. Alasan keempat dan kelima, agar pedagang (tertanggung) bisa hidup lebih tenang dan kesehatan lebih terjamin (masingmasing 9\%). Alasan keenam, karena pedagang yang bersangkutan mampu membayar premi sehingga tertarik berasuransi ( 8 responden atau 8,4\%). Alasan ketujuh, agar pendidikan anak terjamin $(7,4 \%)$. Sedangkan alasan terakhir menurut responden adalah agar harta tidak hilang $(2,1 \%)$.

Faktor yang menjadi penyebab para pedagang tidak tertarik berasuransi antara lain, karena tidak punya uang untuk membayar iuran/premi $(27,4 \%)$, harga premi yang terlalu mahal $(12,6 \%)$, alasan tidak percayanya mereka (pedagang) pada perusahaan asuransi (12,6\%). Ada juga beberapa responden menyatakan ketidaktertarikan berasuransi disebabkan karena tidak ingin berurusan dengan asuransi dan perusahaan asuransi $(6,3 \%)$, merasa aman tanpa asuransi $(5,3 \%)$ dan merasa mampu mengatasi masalah sendiri sehingga tidak perlu ada asuransi (3\%). Sedangkan alasan lainnya karena merasa punya banyak tabungan $(1,1 \%)$, trauma dengan asuransi (1,1\%) dan adanya keyakinan yang penuh pada takdir dan pertolongan Tuhan $(1,1 \%)$. Sayangnya dalam kaitannya dengan pertanyaan ini terdapat $29,5 \%$ responden tidak memberikan pendapatnya.

Berdasarkan hasil penelitian yang dilakukan (tabel $5 \mathrm{~s} / \mathrm{d}$ tabel 10) menunjukkan bahwa tingkat kesadaran hukum (pengetahuan, pemahaman, dan perilaku/budaya) berasuransi para pedagang 
termasuk kategori baik/tinggi. Namun disayangkan, khusus untuk Asuransi Kerugian, data menunjukkan bahwa keinginan para pedagang Kota Medan untuk mengasuransikan barang dagangannya atau harta miliknya (property) pada perusahaan Asuransi Kerugian masih tergolong rendah.

\section{DAFTAR PUSTAKA}

\section{A. Buku}

Kartono, Kartini, 1996, Pengantar Metodologi Riset Sosial, Mandar Maju, Bandung.

Mantiri, Tana (Editor), 2011, Dampak Penyuluhan Hukum terhadap Tingkat Kesadaran Hukum Masyarakat, JBPHN-Kementerian Hukum dan Hak Asasi Manusia Republik Indonesia, Jakarta.

Prakoso, Djoko dan I Ketut Murtika, 2004, Hukum Asuransi Indonesia, Rineka Cipta, Jakarta.

Saebeni, Beni Ahmad, 2006, Sosiologi Hukum, Pustaka Setia, Bandung.

Silalahi, Ulber, 1999, Metode dan Metodologi Penelitian, Bina Budhaya, Bandung.

Sugiyono, 2012, Metode Penelitian Pendidikan Pendekatan Kuantitatif, Kualitatif, dan R\&D, ALFABETA, Bandung.

Widjaya, 1984, Kesadaran Hukum Manusia dan Manusia Pancasila, Era Swasta, Jakarta.

\section{B. Artikel Jurnal}

Kainth, Gursharan Singh, "Environmental Awareness Among School Teachers", The Icfai University Journal of Environmental Economics, Vol. VII, No. 1. 2009.

Sihono,Teguh, "Usaha Kecil dan Menengah (UKM) dan Upaya Mengatasi Pengangguran”, Jurnal Ekonomia, Volume 1 Nomor 1, Agustus 2005.

Susilo,Y.Sri, "Peran Perbankan dalam Pembiayaan UMKM di Provinsi Daerah Istimewa Yogyakarta", Jurnal Keuangan dan Perbankan, Volume 14, Nomor 3, September 2010.

\section{Makalah}

Mertokusumo, Sudikno, "Meningkatkan Kesadaran Hukum Masyarakat", Makalah Dalam Rangka Kerjasama Kampanye Penegakan Hukum antara Fakultas Hukum UGM dengan Kejaksaan Agung RI, Yogyakarta 29 Juli 1978.

\section{Internet}

Anonim, "Kontribusi UKM Terhadap PDB Indonesia", http://iwansidharta.com/berita101-kontribusi-ukm-terhadap-pdb-indonesia.html, diakses 12 Maret 2015.

AndikSismanto, "Lima Kios di Pasar Ganefo Demak Ludes Terbakar", https://daerah.sindonews. com/read/988860/22/lima-kios-di-pasarganefo-demak-ludes-terbakar-1428931753, diakses 15 April 2015.

Bayu Hermawan, "Pasar Soreang Bandung Terbakar", http://nasional.republika.co.id/ berita/nasional/daerah/15/04/10/nmlcttpasar-soreang-bandung-terbakar, diakses 15 April 2015.

Badan Pusat Statistik, "Produk Domestik Bruto", http://www.bps.go.id/index.php?news $=730$, diakses 12 Maret 2015.

Darwis Sarkani, "Pasar Raya Mekongga Kolaka Terbakar", http://antarasultra.com/berita/ 277450/pasar-raya-mekongga-kolakaterbakar, diakses 15 April 2015.

Semarang Bisnis, "Kebakaran Pasar Tayu, Kerugian Sementara Rp30 Miliar", http://semarang. bisnis.com/read/20150129/1/76378/ 
kebakaran-pasar-tayu-kerugian-sementararp30-miliar, diakses 12 April 2015.

Sumbar Satu, "Kebakaran di Pasar Siteba Padang, Tiga Meninggal Terpanggang", http://www. sumbarsatu.com/berita/10013-kebakarandi-pasar-siteba-padang-tiga-meninggalterpanggang, diakses 15 April 2015.

Sudaryanto, Ragimun dan Rahma Rina Wijayanti, "Strategi Pemberdayaan UMKM Menghadapi Pasar Bebas Asean", dalam http:// www.kemenkeu.go.id/sites/default/files/ Strategi\%20Pemberdayaan\%20UMKM.pdf, diakses 12 Maret 2015.

Tribun Jabar, "Kebakaran Pasar Cikurubuk Telan Kerugian Sekitar Rp 23,5 M", http://jabar. tribunnews.com/2015/03/18/kebakaranpasar-cikurubuk-telan-kerugian-sekitar-rp235-m, diakses 15 April 2015.

Tribun Lampung, "Si Jago Merah Lalap Ruko di Pasar Tengah", http://lampung.tribunnews. com/2015/03/30/breaking-news-si-jagomerah-lalap-ruko-di-pasar-tengah, diakses 15 April 2015.

\section{E. Peraturan Perundang-Undangan}

Undang-Undang Nomor 40 Tahun 2014 tentang Perasuransian (Lembaran Negara Republik Indonesia Tahun 2014 Nomor 337, Tambahan Lembaran Negara Republik Indonesia Nomor 5618). 